\title{
Status of farm mechanization of different agro-climatic zones in Uttar Pradesh
}

\section{Rakesh Kumar and Ashok Tripathi}

Received : 02.10.2017; Revised : 28.02.2018; Accepted : 11.03.2018

See end of the Paper for authors' affiliation

Correspondence to :

Rakesh Kumar

Department of Farm Machinery and Power

Engineering, Vaugh Institute of Agricultural Engineering and

Technology, Sam Higginbottom University of Agriculture,

Sciences and Technology,

Allahabad (U.P.) India

Email : rakesh.pal3494@

gmail.com
- ABSTRACT : India accounts for only about 2.4 per cent of the world's geographical area and 4 per cent of its water resources, but has to support about 17 per cent of the world's human population and 15 per cent of the livestock. Agriculture is an important sector of the Indian economy, accounting for 14 per cent of the nation's GDP and about 11per cent of its exports. Agriculture in India is currently growing at an average compound annual growth rate (CAGR) of 2.8 per cent. The estimated numbers of tractors, power tillers, diesel engines and motors per 1000 ha were average found to be 116, 0, 63 and 119, respectively, in Uttar Pradesh. The number of power sources per 1000 ha of net area sown in the selected village of Bareilly, Bulandshahr, Bijnour, Firozabad, Etawah, Jalaun, Kushinagar, Azamgarh and Sonbhadra districts were: Tractors - 108, 172, 152, 159, 104, 106, 75, 104, and 65; Diesel Engines - 91, 91, 81, 36, 51, 15, 29, 85, and 85; and Electric Motors $-108,151,141,165,115,155,14,145$ and 80 , respectively.

- KEY WORDS : Tractor, Diesel engine, Electric motor

- HOW TO CITE THIS PAPER : Kumar, Rakesh and Tripathi, Ashok (2018). Status of farm mechanization of different agro-climatic zones in Uttar Pradesh. Internat. J. Agric. Engg., 11(1) : 180183, DOI: 10.15740/HAS/IJAE/11.1/180-183. 